\title{
Contraception for Women with Diabetes Mellitus
}

\section{Kontrasepsi untuk Perempuan dengan Diabetes Mellitus}

\author{
Wachyu Hadisaputra, Leonita TA Sutrisna \\ Division of Reproductive Health \\ Department of Obstetrics and Gynecology \\ Faculty of Medicine University of Indonesia/ \\ Dr. Cipto Mangunkusumo General Hospital \\ Jakarta
}

\begin{abstract}
Objective: To compare the different types of contraception and its use in women with diabetes mellitus.

Method: Literature review.

Result: Women in the reproductive age who are affected by a wide range of chronic medical conditions, one of which is diabetes mellitus (DM), may experience adverse health effects pre-conception and in pregnancy. This condition will influence outcome of pregnancy and contraceptive choice after delivery. Planning the use of contraception for women with DM who would experience high-risk pregnancy is a necessity, and counseling must consider the safety of different types of contraception that in comparison to the risk of pregnancy. WHO has provided a guideline on choosing contraception, which is available from the UK Medical Eligibility Criteria for Contraceptive Use (UKMEC), as the basis for contraception selection for women with DM. For DM patients without complication any type of contraception can be used in consideration for the advantages and disadvantages of each type of contraception. For diabetics with complications or multiple risk factors, in the selection of contraceptive, hormonal contraception (especially for combined hormonal contraception (CHC) pill and injection method) requires proper consideration and consultation with health care providers.

[Indones J Obstet Gynecol 2014; 4: 226-231]
\end{abstract}

Keywords: complications, contraception, diabetes mellitus, hormonal, pregnancy

\begin{abstract}
Abstrak
Tujuan: Untuk membandingkan berbagai jenis kontrasepsi dan penggunaannya bagi perempuan penderita diabetes mellitus.

Metode: Kajian pustaka.

Hasil: Perempuan usia reproduksi yang dipengaruhi oleh berbagai macam kondisi medis kronis, salah satunya diabetes mellitus (DM), dapat mengalami efek buruk pada kesehatan pada masa prekonsepsi dan dalam kehamilan. Kondisi ini mempengaruhi luaran kehamilan serta pemilihan kontrasepsi setelah persalinan. Perencanaan penggunaan kontrasepsi bagi perempuan dengan DM yang memiliki risiko pada kehamilannya adalah suatu kebutuhan, dan konseling harus memperhitungkan keamanan dari berbagai jenis kontrasepsi dibandingkan dengan risiko dalam kehamilannya. WHO membuat pedoman pemilihan kontrasepsi yang dapat diperoleh dari UK Medical Eligibility Criteria for Contraceptive Use (UKMEC) sebagai dasar pemilihan kontrasepsi bagi perempuan penderita DM. Bagi penderita DM tanpa komplikasi, semua jenis kontrasepsi dapat digunakan dengan memperhitungkan keuntungan dan kerugian dari masing-masing jenis kontrasepsi. Bagi penderita diabetes dengan komplikasi maupun faktor risiko multipel, pada pemilihan kontrasepsi, kontrasepsi hormonal (terutama untuk metode pil kombinasi dan injeksi) memerlukan pertimbangan dan konsultasi yang tepat dengan petugas kesehatan.
\end{abstract}

[Maj Obstet Ginekol Indones 2014; 4: 226-231]

Kata kunci: diabetes mellitus, hormonal, kehamilan, komplikasi, kontrasepsi

\section{INTRODUCTION}

Diabetes is usually a lifelong disease in which there is a high level of glucose concentration in the bloods. ${ }^{1}$ Every year, the prevalence of diabetes mellitus (DM) increases in many countries around the world. It is estimated that by the year 2030 the prevalence of DM in Indonesia will reach 21.3 million people. ${ }^{2}$ Results of Basic Health Research (Riskesdas) in 2007, found that the proportion of death caused by DM in the age group 45-54 years in urban areas is the second highest at $14.7 \%$. Meanwhile, in rural areas DM ranks as the sixth most common cause of death at $5.8 \%{ }^{2}$
In obstetrics and gynecology, diabetes mellitus is a special concern. Women in the reproductive age are affected by many chronic medical conditions that have important effects on the preconception health of the woman and on pregnancy outcomes. ${ }^{3}$ The increased prevalence of DM influence outcome of pregnancy and choice of contraception after delivery.

In Indonesia, the number of contraceptive users is quite high. National Socioeconomic Survey (Susenas) in 2004 showed that the contraception prevalence rate was $56.71 \%$ in Indonesia. This means that one in two couples of childbearing age 
in Indonesia in 2004 was using a form contraceptive. The difference of contraceptive prevalence rate in urban and rural areas is very small, which shows that the approach strategy of family planning programs in urban and rural areas is almost equal. ${ }^{4}$ Nowadays, the estimated Contraceptive Prevalence Rate (CPR) or the number of contraceptive users in Indonesia has reached $62 \%$. The types of contraception utilized include injection $(50.46 \%)$, oral contraceptive (27.94\%), intrauterine device (IUD) (6.61\%), implant (6.87\%), tubal ligation $(1.5 \%)$, condom $(6.47 \%)$, and vasectomy $(0.34 \%) .{ }^{5}$ The majority of women will select and pay out-of-pocket for the various methods of available contraception. This is because the different methods of contraception chosen have different effectiveness. Planning contraceptive use for women with DM who still have full reproductive capacity is very important, and the safety of different types of contraception in comparison with the risk DM in pregnancy must be considered during counseling. ${ }^{6}$

\section{DIABETES MELLITUS}

According to WHO (2006) DM is a metabolic disorder characterized by high levels of sugar in the blood, also called hyperglycemia, with impaired metabolism of carbohydrates, fats and proteins caused by impairment in insulin production and non-optimal action of insulin. ${ }^{1,7}$ The normal blood glucose levels ranged from 3.6 to $6.1 \mathrm{mmol} / \mathrm{l}$ (65$110 \mathrm{mg} / \mathrm{dl}$ ). After food consumption, the concentration will range between 4.5 - $5.5 \mathrm{mmol} / \mathrm{l}$. After consumption of high-carbohydrate food, the concentration will increase to 6.5 to $7.2 \mathrm{mmol} / \mathrm{l}$. On the other hand, when fasting blood glucose levels may reach 3.3 to $3.9 \mathrm{mmol} / \mathrm{l} .1,5,7$

The WHO diagnostic criteria for diabetes include presence of classic symptoms such as polyuria, polydypsia, poliphagia, and weight loss with no apparent reason, as well as glucose level on random blood glucose test (RBG) $11.1 \mathrm{mmol} / \mathrm{l}(200 \mathrm{mg} / \mathrm{dl})$ fasting blood glucose (FBG) $7.0 \mathrm{mmol} / \mathrm{l}$ $(126 \mathrm{mg} / \mathrm{dl})$ or Oral Glucose Tolerance Test (OGTT) $11.1 \mathrm{mmol} / \mathrm{l}(200 \mathrm{mg} / \mathrm{dl})$. Random blood glucose is the result of an examination without considering the last meal time. Fasting means the patient does not eat for at least 8 hours. Mean-while, OGTT con- ducted by WHO standards, uses a glucose load equivalent to $75 \mathrm{~g}$ of glucose anhidrus dissolved into the water. ${ }^{7-10}$

Classification of DM in Pregnancy by Pyke includes 3 classes, as follows: Class I involves gestational diabetes, which is diabetes arising during pregnancy and disappearing after delivery; Class II or pregestational diabetes, which is diabetes starting since before pregnancy and continuing after pregnancy; Class III comprises all pregestational complications of diabetes, which may include vascular diseases such as retinopathy, nephropathy, pelvic inflammatory disease and peripheral vascular disease. Furthermore, DM may lead to various complications in relation to pregnancy, both for the mother and the baby. These complications can lead to disability or death. ${ }^{11}$

\section{CONTRACEPTION}

Contraception is an attempt to prevent the occurrence of pregnancy, which may be temporary or permanent. The use of contraception is one of the variables influencing the variable of fertility. ${ }^{12}$ The basic of contraception selection is the intended use of contraception itself. The purpose of the selection of contraceptive is divided into three, namely to delay pregnancy, to space pregnancy, or to end reproductive capacity. ${ }^{13}$

In addition, the factors influencing women in choosing a contraceptive method include individual acceptor factors, personal health factors and contraceptive method factors. The individual acceptor factors consist of age, lifestyle, frequency of intercourse, the number of children desired, and previous contraceptive experience. Personal health factors include health status, menstrual history, family history, physical examination results, and pelvic examination result. Contraceptive method factors consist of effectiveness, side effects, and cost. $^{14}$

\section{TYPES OF CONTRACEPTION}

WHO has published a guideline on choosing contraceptive method for any women which is available from the UK Medical Eligibility Criteria for Contraceptive Use (UKMEC). ${ }^{15}$ 
Table 1. Guideline on Choosing contraception from UKMEC 15

UKMEC categories

UKMEC 1 A condition for which there is no restriction for the use of the contraceptive method

UKMEC 2 A condition where the advantages of using the method generally outweigh the theoretical or proven risks

UKMEC 3 A condition where the theoretical or proven risks generally outweigh the advantages of using the method Provision of a method to a woman with a condition given a UKMEC category 3 requires expert clinical judgement and/or referral to a specialist contraceptive provider, since use of the method is not usually recommended unless other methods are not available or not acceptable

UKMEC 4

A condition which represents an unacceptable health risk if the contraceptive method is used

In women with DM, the selection of appropriate contraceptive with UKMEC category can be seen in the following table.

Table 2. UKMEC Category for Women with Diabetes Mellitus ${ }^{15}$

\begin{tabular}{|c|c|c|c|c|c|c|c|c|}
\hline \multicolumn{9}{|c|}{ UKMEC category recommendations on choosing contraception for women with diabetes } \\
\hline Diabetes & $\mathrm{CHC}$ & POP & $\begin{array}{l}\text { DMPA/ } \\
\text { NET-EN }\end{array}$ & Implant & IUD & IUS & Barrier & Sterilization \\
\hline $\begin{array}{l}\text { Without vascular disease } \\
\text { Non-insulin-dependent } \\
\text { Insulin-dependent }\end{array}$ & $\begin{array}{l}2 \\
2\end{array}$ & $\begin{array}{l}2 \\
2\end{array}$ & $\begin{array}{l}2 \\
2\end{array}$ & $\begin{array}{l}2 \\
2\end{array}$ & $\begin{array}{l}1 \\
1\end{array}$ & $\begin{array}{l}2 \\
2\end{array}$ & $\begin{array}{l}1 \\
2\end{array}$ & $\begin{array}{l}\text { Caution: the procedure is normally conduc- } \\
\text { ted in a routine setting, but with extra pre- } \\
\text { paration, precautions and conselling }\end{array}$ \\
\hline $\begin{array}{l}\text { Nephropathy } \\
\text { Retinopathy } \\
\text { Neuropathy }\end{array}$ & 3 or 4 & 2 & 3 & 2 & 1 & 2 & 1 & $\begin{array}{l}\text { Special: the procedure should be under- } \\
\text { taken in a setting with an experienced } \\
\text { surgeon and staff }\end{array}$ \\
\hline $\begin{array}{l}\text { With other vascular } \\
\text { disease }\end{array}$ & 3 or 4 & 2 & 3 & 2 & 1 & 2 & 1 & $\begin{array}{l}\text { Special: the procedure should be under- } \\
\text { taken in a setting with an experienced sur- } \\
\text { geon and staff }\end{array}$ \\
\hline $\begin{array}{l}\text { History of gestational } \\
\text { diabetes }\end{array}$ & 1 & 1 & 1 & 1 & 1 & 1 & 1 & $\begin{array}{l}\text { Accept: there is no medical reason to deny } \\
\text { sterilization to a woman with this condition }\end{array}$ \\
\hline
\end{tabular}

CHC=combined oral contraception; DMPA/NET-EN=depot medroxyprogesterone acetate/norethisterone enantate; IUD=copper-bearing intrauterine device; IUS=levonorgestrel-releasing intrauterine system; $P O P=$ progestogen-only pill

\section{Simple Method}

This method consists of periodic abstinence, calendar method, basal body temperature method, cervical mucus method, Sympto-Thermal method, and coitus interruptus. ${ }^{14}$ These methods require compliance and accuracy from married couples. However, the effectiveness and efficiency of these methods is low. Although fertility awareness methods can provide effective contraception to those motivated to use them, little is known about the effectiveness of these methods in women with chronic disease. Women with diabetes may experience variation in their menstrual cycles, which is associated with a higher failure rate for this method.6,15

\section{With Device}

This method includes the mechanical (barrier) which consists of male condoms and intra-vaginal barrier, and chemical (Spermisid) which consists of a vaginal cream, vaginal foam, jelly vaginal, vaginal suppositories, vaginal tablets and vaginal soluble films. ${ }^{14}$ These methods can be effective contraceptive methods when used consistently and correctly. However, these methods typically have the highest failure rates because they are user-dependent, with efficacy rates depending on patient adherence to recommended use. ${ }^{6}$ Therefore, to prevent the risk of pregnancy in women with diabetes, proper education regarding the use of these methods is necessary. ${ }^{6,15}$ 


\section{Modern Methods}

\section{Pill}

Birth control pills usually contain estrogen and progesterone. The mechanism of the pill is to replace normal estrogen and progesterone production and suppress the hormones produced by the ovaries and the factors released by the brain so that ovulation can be prevented. The effectiveness of this method theoretically reaches $99 \%$ or 0.1 to 5 pregnancies per 100 women in the first year usage when used appropriately. But in practice it turns out the pill failure rate is still quite high, reaching 0.7 to $7 \% .^{14}$

The pill has an effect on carbohydrate metabolism, although the clinical impact appears to be unclear. ${ }^{15,16}$ The effect of elevated glucose levels in the blood is a result of the decreased blood glucose tolerance. ${ }^{5}$

On the other hand, in Thailand, Suwikroma and Jaisamrarnb suggested that low dose combination contraceptive pill taken by women over the age of 40 years, can improve glucose tolerance and lower fasting blood glucose levels, making it safe for use. ${ }^{5,17}$ The combination hormonal contraception (CHC) is now considered a safe option for women with uncomplicated, well-controlled type 1 or type 2 diabetes (UKMEC 2). CHC is not recommended for women with multiple cardiovascular risk factors (UKMEC 3 or 4).6,15,16

Progestin-only pills are suitable for women with DM of any age with or without complications (UKMEC 2). This safety rating makes these pills an appropriate choice for individuals who have diabetes with hypertension or vascular disease. ${ }^{15,16}$

\section{Injectable Contraceptives}

The most commonly available injectable contraceptive is Depo-Provera, which is a progestin-only preparation administered every 3 months. The mechanism of action of injectable contraceptives is by preventing ovulation, thickening the cervical mucus, and inhibiting the cyclic development of endometrium. The effectiveness of injectable contraceptives is very high, with failure rate as low as 0.3 pregnancies per 100 women during the first year of use. ${ }^{14}$

Depot medroxyprogesterone acetate (DMPA) and norethisterone enantate (NET-EN) injections are long-acting reversible methods, and both are indicated for women with uncomplicated diabetes (UKMEC 2). However, injectable contraception is not recommended for women with diabetic complications (UKMEC 3) due to concerns about possible negative impact on lipid metabolism and change in glucose tolerance. $6,15,16$

\section{Implant}

The most frequently used contraceptive implants are Norplant. Norplant is a subdermal implant contraceptive containing levonorgestrel (LNG) as the active ingredient. The mechanism of action of Norplant is unclear but might be the same as other methods containing only progestin. Norplant has the effect of preventing ovulation, thickening the cervical mucus, and inhibiting the cyclic development of endometrium. The effectiveness of Norplant is very high, with failure rate of only 0.05 to 1 pregnancy per 100 women in the first year of use. Norplant failure rate is $<1$ pregnancy per 100 women per year in the first 5 years of use. The failure rate was lower when compared with barrier methods, birth control pills, and IUDs. ${ }^{14}$

Norplant, comparable with other hormonal contraceptives containing progestin, was found to have minimal effect on carbohydrate metabolism, improves glycemic $(12.3 \%)$ and insulin $(37.7 \%)$ response after oral glucose tolerance test, although such effects were not observed clinically. ${ }^{16,18}$ Several studies have debated the effects of the use of implants in women with DM. There have been several reports of a decrease in insulin sensitivity after use of implants. The resulting increase in relative weight associated with contraceptive use is possibly caused by insulin resistance. ${ }^{16,19}$ The etonogestrel-releasing implant is safe (UKMEC 2) for women with DM and provides the highest efficacy among other reversible contraceptives. ${ }^{6}$

\section{IUDs (Intrauterine Device)}

The mechanism of action is not clearly understood but it is likely that IUDs causes changes such as the appearance of inflammatory cells that destroys blastocyst or spermatozoa, thus increasing the inhibition of implantation, as well as accelerating movement of ovum in the fallopian tube. The effectiveness of IUDs reaches 0.6 to 0.8 pregnancies per 100 women during the first year of use. IUD failure rate is $1-3$ pregnancies per 100 women per year. ${ }^{14}$ 
Copper-bearing intrauterine devices are suitable for all women with DM (UKMEC 1). IUDs offer effective contraception without hormonal or metabolic side-effects and is another long-acting reversible method. During the late 1970s, the possible problem of IUDs in insulin-dependent diabetes mellitus (IDDM) emerged. This was at a time when the concern was that IUDs could cause pelvic inflammatory disease. It has since been disputed, and IUDs are considered to be equally effective in woman with and without diabetes.The levonogestrelreleasing intrauterine system (IUS) is also suitable choice for many women with diabetes. The IUS is classified as UKMEC 2 because of a theoretical concern that levonogestrel may influence carbohydrate and lipid metabolism. ${ }^{15,20-22}$

\section{Permanent Contraception (Sterilization)}

Permanent contraception is divided into two kinds Medical Operation for Men (MOP) and Medical Operation for Women (MOW). ${ }^{14}$ For women who felt they have completed childbearing or are confident they will never desire pregnancy, surgical sterilization is an excellent option, especially for women with DM because of the higher risk of pregnancy complication. UKMEC stipulate that in women with diabetic complications or with poorly controlled diabetes, sterilization should be undertaken in a specialist setting with access to experienced surgical and anaesthetic staff. This is because of the possibility of hypoglycemia or ketoacidosis, increased risk of wound infection and delayed healing. Prophylactic antibiotics are recommended before surgical sterilization. $6,15,20$

\section{CONCLUSION}

Contraception selection for women in the reproductive age with a chronic disease like DM should be a special concern. Based on UKMEC category, patient condition is divided into four categories. UKMEC 1 and 2 represents conditions that allow use of contraception with consideration on every advantages and disadvantages of each method. UKEC 3 represents the use of methods requiring expert clinical judgement and not usually recommended unless other methods are not available or not acceptable. UKMEC 4 represents a condition that is not suitable for use of a specific method of contraception.
For DM patients without complication any type of contraception can be used with consideration for the advantages and disadvantages of each type of contraception (UKMEC 1 or 2). For diabetics with complications or multiple risk factors, in consideration for contraceptive selection, hormonal contraception (especially combined hormonal contraception (CHC) pill and injection method) requires proper consideration and consultation with health care providers (UKMEC 3 or 4).

\section{REFERENCES}

1. Topiwala S. Diabetes. [Online]. 2012 [update 2012 Jun 27; cited 2014 Feb 17]. Available from: URL:http://www.ncbi. nlm.nih.gov/pubmedhealth/PMH0002194/

2. Sekertariat Jendral Departemen Kesehatan. Tahun 2003 prevalensi diabetes mellitus di Indonesia mencapai 21,3 juta orang. Indonesia: Pusat Komunikasi Publik, Sekretariat Jenderal Departemen Kesehatan; 2004.

3. Nojomi M, Morrovatdar N, Davoudi F, et al. Contraceptive use by Iranian women with hypertension, diabetes or obesity. EMHJ 2013; 19(7): 638-43.

4. Data Statistik Indonesia. Angka Prevalensi Pemakaian Kontrasepsi. Indonesia: Data Statistik Indonesia; 2014.

5. Widodo FY. Efek pemakaian pil kontrasepsi kombinasi terhadap kadar glukosa darah. Surabaya: Universitas Wijaya Kusuma; 2011 Jul. Available from: URL:http://elib.fkuwks. ac.id/asset/archieve/jurnal/vol1.no2.Juli2011/EFEK\%20PE MAKAIAN\%20PIL\%20KONTRASEPSI\%20KOMBINASI.pdf

6. Broecker JED, Lykens JE. Contraceptive options for women with diabetes mellitus: an evidence-based guide to safety and patient counseling. AOA Health Watch. 2011: 11-8.

7. Ambarwati WN. Konseling pencegahan dan penatalaksanaan penderita diabetes mellitus. Available from: URL:http: //publikasiilmiah.ums.ac.id/bitstream/handle/12345678 9/2831/Winarsih\%20Nur\%20A.pdf?sequence=1

8. WHO/IDF Consultation. Definition and diagnosis of diabetes mellitus and intermediate hyperglicemia. Geneva: WHO; 2006.

9. Cagnacci A, Ferrari S, Tirelli A, et al. Route of administration of contraceptives containing desogestrel/etonorgestrel and insulin sensitivity: a prospective randomized study. Contraception 2009; 80(1): 34-9.

10. Godsland IF, Walton C, Felton C, et al. Insulin resistance, secretion, and metabolism in users of oral contraceptives. J Clin Endocrinol Metab 1992; 74(1): 64-70.

11. Universitas Sumatera Utara. Diabetes mellitus. Available from: URL:http://usupress.usu.ac.id/files/Penyakit-

12. Prawirohardjo S. Buku Acuan Nasional Pelayanan Kesehatan Maternal dan Neonatal. Jakarta:YBP-SP; 2006.

13. Qolbi L. Gambaran berat badan ibu sebelum dan sesudah menggunakan KP suntik depo medroxy progesterone asetat di BPS Yati Agustianingsih Kebonagung Demak 2009. Available from: URL:http://digilib.unimus.ac.id/files/disk1/102/jtptunimus-gdl-lutfiatulq-5082-3-bab2.pdf

14. Tedjo LIK. Faktor-faktor yang mempengaruhi pemilihan jenis kontrasepsi yang digunakan pada keluarga miskin. 2009. Available from: http://eprints.undip.ac.id/18903/1/ Laksmi_Indira_Kartini_Tedjo.pdf 
15. Shawe J. Contraceptive choices for women with diabetes. Bri J Primary Care Nursing 2013; 10(2): 79-82.

16. Pallardo LF, Cano A, Cristobal I, et al. Hormonal contraception and diabetes. Clinical Medicine Insights: Women's Health 2012; 5: 53-63.

17. Suwikroma S, Jaisamram U. Comparison of the metabolic effects of oral contraceptive and nonhormonal contraceptive use in women over 40 years old. Contraception 2005; 71(3): 183-7.

18. Powers AC. Harrison's Principles of Internal Medicine vol II. 17 $^{\text {th }}$ ed. New York: McGraw-Hill Medical; 2008: 22752304.
19. McPhee SJ, Papadakis MA, Rabow MW. Current Medical Diagnosis and Treatment. $15^{\text {th }}$ ed. New York: The McGraw-Hill Companies Inc.; 2011.

20. Goldstuck ND, Steyn PS. The intrauterine device in women with diabetes mellitus type I and II: a systematic review. ISRN Obstet Gynecol 2013; 22: 1-6.

21. Rogovskaya S, Rivera DAG. Effect of a levonogestrel intrauterine system on women with type 1 diabetes: a randomized trial. Obstet Gynecol 2005; 105(4): 811-5.

22. World Health Organization. Improving access to quality care in family planning: medical eligibility criteria for contraceptive use. Geneva: World Health Organization; 2000. 